\title{
HUBUNGAN INTERAKSI SOSIAL DENGAN KUALITAS HIDUP LANSIA DI WILAYAH KERJA PUSKESMAS BANGKALA KELURAHAN BIRING ROMANG
}

\author{
${ }^{1}$ Kurniawan Amin \\ ${ }^{2}$ Sigit Mulyono \\ ${ }^{3}$ Lili Herlina \\ ${ }^{1}$ Fakultas Keperawatan Universitas Mega Resky Makassar, Indonesia \\ ${ }^{2}$ Fakultas Keperawatan Universitas Indonesia Jakarta, Indonesia \\ ${ }^{3}$ Fakultas Keperawatan Universitas Muhammadiyah Jakarta, Indonesia
}

\begin{abstract}
Alamat Korespondensi:
Kurniawan Amin,S.Kep,Ns,M.Kep

Keperawatan Komunitas Universitas Mega Rezky

Hp : 085299600137

E-mail: Kurniawanamin@yahoo.com
\end{abstract}




\begin{abstract}
ABSTRAK
Kualitas hidup adalah tingkatan yang menggambarkan keunggulan seorang individu yang dapat dinilai dari kehidupan mereka. Tujuan dari penelitian ini adalah untuk mengetahui Hubungan Interaksi Sosial dengan kualitas hidup lansia di Wilayah Kerja Puskesmas Bangkala, Kel. Biring Romang, Kec Manggala, Kota Makassar. Metode: Penelitian ini merupakan penelitian kuantitatif dengan jenis penelitian Kroseksional Studi dengan besar sampel 219 Responden dengan menggunakan uji Che Square. Hasil penelitian menunjukkan bahwa interaksi menggunakan media sosial pada lansia $\mathrm{P}$ value $=0,000$ yang artinya ada hubungan yang signifikan antara interaksi sosial dengan kualitas hidup pada lansia di wilayah kerja Puskesmas Bangkala, Kel.Biring Romang, Kec. Manggala, Kota Makassar. Kesimpulan: Ada hubungan antara interaksi sosial dengan kualitas hidup pada lansia, oleh karena itu diharapkan bahwa seorang lansia mestinya secara perlahan harus diperkenal dalam proses kehidupan sehari-harinya bisa melakukan interaksi sosial.
\end{abstract}

\title{
Kata Kunci : Interaksi Sosial, Kualitas Hidup
}

\begin{abstract}
ABSTRAC
Quality of life is a level that describes the advantages of an individual that can be assessed from their lives. The purpose of this study was to determine the relationship of social interaction with the quality of life of the elderly in the work area of Bangkala Health Center, Kel. Biring Romang, Kec Manggala, Makassar City. Method: This research is a quantitative study with a type of research with cross-sectional studies with a sample size of 219 respondents using a computerized application of SPSS 20 Che Square test. The results showed that interaction using social media in the elderly P-value $=0,000$, which means there is a significant relationship between quality of life in the elderly in the area of Bangkala Health Center, Kel. Biring Romang, Kec. Manggala, Makassar City. Conclusion: There is a relationship between quality of life in the elderly, therefore it is expected that an elderly person should slowly be acquainted with so that in the process of daily life can do social interaction.
\end{abstract}

Keywords: Social Interaction, Quality of Life 
PENDAHULUAN

Indikator

keberhasilan

dari

pembagunan suatu negara adalah

meningkatnya usia harapan hidup penduduk

suatu Negara tersebut. Usia lanjut merupakan suatu kejadian yang pasti akan dialami oleh semua orang dan terjadinya tidak bisa dihindari oleh siapapun.World Health Organization (WHO) menetapkan usia lebih dari 60 tahun sebagai usia yang menunjukkan proses menua dan berlangsung secara nyata. (Organization, 2004).

Penggolongan lansia menurut World Health Organization (WHO) meliputi : middle age (45-49 tahun), elderly (60-74 tahun), old (75-79 tahun), very old (di atas 90 tahun). Maningkatnya usia harapan hidup manusia berdampak terhadap jumlah populasi lansia. Rata-rata usia harapan hidup di negara-negara kawasan Asia Tenggara adalah 70 tahun, sedangkan usia harapan hidup di Indonesia sendiri termasuk cukup tinggi yaitu 71 tahun, (Fitria, 2011).

Menua bukanlah suatu penyakit tetapi merupakan proses berkurangnya daya tahan tubuh dalam menghadapi rangsangan dari dalam maupun luar tubuh. Proses menua sudah mulai berlangsung sejak seseorang mencapai usia dewasa, misalnya dengan terjadinya kehilangan jaringan pada otot, susunan saraf, dan jaringan lain sehinggah tubuh mati sedikit demi sedikit (Azizah, 2011).

Interaksi sosial merupakan hubungan timbal balik atau hubungan yang saling mempengaruhi antar manusia yang berlangsung sepanjang hidupnya dalam masyarakat. Interaksi sosial dapat berdampak positif terhadap kualitas hidup karena adanya interaksi sosial maka lansia tidak merasa kesepian, oleh sebab itu, interaksi sosial harus tetap dipertahankan dan dikembangkan kelompok lansia. Kemampuan lansia untuk terus menjalin interaksi sosial merupakan kunci untuk mempertahankan status sosialnya berdasarkan kemampuan

bersosialisasi, (Fitriyadewi \& Suarya, 2016).

World Health Organization Quality Of Life atau WHOQL mendefenisikan kualitas hidup sebagai persepsi individu terhadap kehidupannya di masyarakat dalam konteks budaya dan sistem nilai yang ada yang terkait dengan tujuan, harapan, standar, dan juga perhatian. Kualitas hidup dalam hal ini merupakan suatu konsep yang sangat luas yang dipengaruhi kondisi fisik individu, psikologis, tingkat kemandirian, serta hubungan individu dengan lingkungan. (Fitriyadewi \& Suarya, 2016).

Dalam konsep teori Imogene M.King interaksi sosial dapat dipengaruhi dari beberapa factor yaitu bahwa manusia dipandang seutuhnya sebagai system yang 
terbuka secara konsisten akan berinteraksi dengan lingkungannya. Imogene M.King juga memadukan dari tiga system interaksi yang dimana system tersebut adalah dinamis yaitu personal, interpersonal, dan sosial yang mengarah kepada pengembangan teori pencapaiann tujuan. Dalam pandangan manusia seutuhnya meliputi sosial, perasaan, rasional, reaksi, control, tujuan, orientasi kegiatan dan berorientasi pada waktu. (Christensen \& Kenney, 2009)

Berdasarkan data dari puskesmas Bangkala tahun 2018 saat ini jumlah keseluruhan lansia sebanyak 1106 orang, ada 2 kelurahan di wilayah kerja Puskesmas Bangkala yaitu Kel. Bangkala, Kel Biring Romang, serta 17 RW. Terdapat 8 posyandu lansia yang berada diwilayah kerja puskesmas bangkala, 4 posyandu di Kelurahan Bangkala dan 4 posyandu di Kel.Biring Romang. Jumlah lansia di Kel.Biring Romang umur 60-74 tahun sebanyak 315 orang, umur 75-90 tahun sebanyak 162 orang, jadi jumlah keseluruhan sebanyak 477 orang.

Berdasarkan wawancara dengan petugas puskesmas dan kader posyandu di wilayah kerja puskesmas bangkala saat ini di RW 02 sekitar $60 \%$ lansia yang kurang berinterksi dan menarik diri dengan masyarakat menyebabkan banyak lansia yang kesehatanya tergangu dan menderita beberapa jenis penyakit khususnya penyakit hipertensi dan Atritis Rhematoid sehingga kualitas hidupnya tidak baik. Dilahat dari ffhasil pemeriksaan kesehatan di posbindu RW 02 sebagian besar lansia menderita penyakit atritis remathoid dan hipertensi dan atas dasar penyakit itu pula banyak lansia tidak aktif dalam mengikuti kegiatan posyandu.

Berdasarkan data dari kader posyandu lansia Anyelir VIII di kelurahan Biring Romang, jumlah lansia di RW 02 yaitu 109 lansia. Dari hasil wawancara 7 orang lansia mengatakan bahwa rata-rata lansia kurang melakukan interaksi sosial dangan masyarakat sekitar dan lebih memilih untuk tinggal dirumah saja sehingga akan mempengaruhi kualitas hidupnya menjadi tidak baik dan ada pula yang memiliki kualitas hidup yang baik tetapi memiliki interaksi sosialnya kurang.

\section{METODE}

Metode penelitian yang digunakan adalah Deskriptif Analitik dengan pendekatan cross sectional. Populasi dalam penelitian ini di wilayah kerja Puskesmas Bangkala, Kelurahan Biring Romang, yang akan diteliti oleh peneliti yaitu populasi sebanyak 477 orang lansia. Teknik pengambilan sampel pada penelitian ini adalah Random Sampling, dengan kriteria inklusi peneliti mengambil sampel yang mewakili yaitu lanjut usia yang tinggal di Wilayah kerja puskesmas bangkala 
Kel. Biring Romang Kec. Manggala yaitu 219 orang lansia.

\section{HASIL}

Berdasarkan Tabel.1 dapat diketahui bahwa Karakteristik responden berdasarkan usia diketahui dari 219 orang lansia mayoritas $94,1 \%$ berusia $60-74$ th, berdasarkan jenis kelamin mayoritas 81,3 $\%$ berjenis kelamin perempuan, berdasarkan pendidikan terakhir mayoritas $88,1 \%$ berpendidikan rendah, berdasarkan penghasilan perbulan mayoritas $92,7 \%$ penghasilan kurang dari upah minimum propinsi Selawesi Selatan ( $\operatorname{Rp} 2.700 .000)$.

Berdasarkan Tabel.2, dapat dikemukakan bahwa sebagian besar responden yang memiliki interaksi sosial kurang yaitu sebanyak 77 orang $(35,2 \%)$, dan lansia yang memiliki kualitas hidup kurang yaitu sebanyak 82 orang $(37,4 \%)$.

\section{PEMBAHASAN}

Berdasarkan hasil penelitian yang dilakukan di Kelurahan Biring Romang, Kecamatan Manggala terdapat 219 orang responden,Hasil penelitian mengenai interaksi sosial, responden yang berada di Kelurahan Biring Romang yang mempunyai interaksi sosial yang baik sebanyak $142(64,8 \%)$ responden, dengan nilai $P$ value 0,003 , ini menandakan bahwa ada hubungan yang signifikan antara interaksi sosial dengan kualitas hidup. Media sosial adalah media online yang mendukung interaksi sosial dan media sosial menggunakan teknologi berbasis web yang mengubah komunikasi menjadi dialo g interaktif. Media sosial sebagai "sebuah kelompok aplikasi berbasis internet yang membangun diatas dasar ideology dan teknologiWeb 2.0 dan yang memungkinkan penciptaan dan pertukaran user generated"c ontent".

Jejaring sosial merupakan situs di manasetiap orang biasa membuat webpa ge pribadi, kemudian terhubung dengan te man teman untuk berbagi informasi dan berkomunikasi.

Jejaring sosial terbesarantara lain $F$ acebook,Myspace, dan Twitter. Jika media tradisional menggunakan media cetak dan media broadcast, maka media sosial menggunakan internet. Media sosial mengajak siapa saja yang tertarik untuk berpertisipasi dengan memberi kontribusi dan feedback secara terbuka, member komentar, erta membagi informasi dalam waktu yang cepat dan tak terbatas. (Kaplan \& Haenlein, 2010)

Dari hasil penelitian yang dilakukan Anang (2016), media sosial memiliki dampak positif dan negatif. Dampak positif penggunaan media sosial secara nyat atelah membawa pengaruh terhadap perubahan sosial masyarakat kearah yang lebih baik tetapi dampak negati fcenderung membawa perubahan sosi almasyarakat yang menghilangkan nilai ni 
laiatau norma di masyarakat Indonesia.Den gan hadirnya media sosial sebagai teknologi baru, tentu saja cara hidup manusia juga akan mengalami perubahan. Beberapap erubahan adalah semakin efektif da n efisiennya manusia dalam mempero lehinformasi tidak terhalang waktu, tempat dan biaya yang tidak terlalu mahal. (Cahyono, 2016)

Pada penelitian yang dilakukan Hope, Schwaba dan Piper (2014). Lansia yang telah mengadopsi teknologi ini juga mengalami hal yang sama. Para lansia tersebut memandang media sosial sebagai alat untuk berkomunikasi dengan berbag aigenerasi tanpa adanya suatu halangan tertentu karena budaya kolektif cenderung memandang keperluan kelompok lebih penting daripada keperluan individu. Akibatnya, demi menjaga kerekatan dan kolektivitas kelompok tersebut, lansia mau membuka diri untuk mempelajari media sosial, meskipun mayoritas penggunanya adalah anak muda. (Hope, Schwaba, \& Piper, 2014)

Dari hasil penelitian yang dilakukan oleh peneliti di tempat penelitian Kelurahan Bangkala Kecamatan Manggala Kota Makassar Tahun 2019, peneliti berasumsi bahwa lansia yang melakukan interkasi sosial dengan menggunakan media sosial pada umumnya sering dilakukan, dilihat pada saat dilakukanya proses penelitian sebagian besar lansia memiliki alat komunikasi tersebut yaitu Hendpon. Walaupun Pada dasarnya Hp yang dimilki seorang lansia tersebut masih belum berbasis android, tetapi media sosial seperti Hp tersebut sangat membantu dalam hal untuk melakukan interaksi sosial dengan sesama lansia.

Selain itu dari hasil peneliti yang telah dilakukan maka peneliti dapat berasumsi bahwa media sosial sangat berperang penting dalam proses peningkatan kualitas hidup lansia, sebab dengan adanaya media sosial seorang lansia akan dengan mudah melakukan interaksi sosial dengan sesama lansia dan keluarganya sehingga seorang lansia tidak merasa kesepian dan selalu merasa diperhatikan oleh keluaraganya dan masyarakat disekitarnya. Dengan adanya media sosial petugas kesehatan khususnya koordinator pelaksana Posyandu lansia akan dengan mudah memberikan informasi tentang kegiatan-kegiatan yang akan dilakukan serta untuk mengigatkan kepada semua peserta posyandu lansia untuk aktif dalam kegiatan tersebut.

\section{KESIMPULAN DAN SARAN}

Hasil penelitian hubungan interaksi sosial 1 dengan kualitas hidup lansia dapat diuraikan sebagai berikut : Karakteristik lansia mayoritas berumur ederli, jenis kelamin perempuan, dengan pendidikan terakhir paling dominan berpendidikan rendah, dan berpenghasilan mayoritas 
penghasilan rendah dibawah upah minimum provinsi Sulawesi Selatan. Presentasi responden pada penelitian ini mayoritas memiliki interaksi sosial baik, dan mayoritas memiliki kualitas hidup yang baik. Ada hubungan antara interaksi sosial dengan kualitas hidup pada lansia dengan nilai $P$ value 0,003 lebih kecil dari variabel yang lainya. Ada hubungan yang dominan yakni interaksi sosial dengan kualitas hidup yang memiliki nilai Exp (B) lebih besar dibandikan variabel yang lainya.

\section{DAFTAR PUSTAKA}

APJII, A. P. (2016). Infografis Penetrasi dan Perilaku Pengguna Internet Indonesia Survei 2016.

Azizah, L. M. (2011). Keperawatan lanjut usia. Yogyakarta: Graha Ilmu, 45.

Cahyono, A. S. (2016). Pengaruh media sosial terhadap perubahan sosial masyarakat di Indonesia. Jurnal Publiciana, 9(1), 140 157.

Christensen, P. J., \& Kenney, J. W. (2009). Proses keperawatan aplikasi model konseptual. Y. Yuningsih \& Yasmin Asih, Eds, 1.

Fitria, A. (2011). Interaksi Sosial dan Kualitas Hidup Lansia di Panti Wredha UPT Pelayanan Sosial Lanjut Usia dan Anak Balita Wilayah Binjai dan Medan. Medan: USU.

Fitriyadewi, W. L., \& Suarya, S. K. (2016). Peran interaksi sosial terhadap kepuasan hidup lansia. Jurnal Psikologi Udayana, 3(2), 332-341.

Hope, A., Schwaba, T., \& Piper, A. M.
(2014). Understanding digital and material social communications for older adults. In Proceedings of the SIGCHI Conference on Human Factors in Computing Systems (pp. 3903-3912).

Kaplan, A. M., \& Haenlein, M. (2010). Users of the world, unite! The challenges and opportunities of Social Media. Business Horizons, 53(1), 59-68.

Organization, W. H. (2004). The world health organization quality of life (WHOQOL)-BREF. World Health Organization.

Statistik, B. P. (2015). Statistik Penduduk Lanjut Usia Indonesia 2015. Diunduh Dari Http://www.

Bps.Go.id/website/pdf_publikasi/StatistikPenduduk-Lanjut-Usia-2015--. Pdf. 
Tabel 1

Distribusi Responden Berdasarkan Usia, Jenis Kelamin, Pendidikan Terakhir,Penghasilan Perbulan dan Media Sosial

\begin{tabular}{ccc}
\hline $\begin{array}{c}\text { Variabel } \\
\text { Usia }\end{array}$ & Frekuensi & Persentase (\%) \\
$-\quad 60-74 \mathrm{Th}$ & 206 & 94,1 \\
$-\quad 75-90 \mathrm{Th}$ & 13 & 5,9 \\
\hline Jenis Kelamin & & 18,7 \\
$-\quad$ Laki laki & 41 & 81,3 \\
$-\quad$ Perempuan & 178 & 88,1 \\
\hline Pendidikan Terakhir & & 11,9 \\
$-\quad$ Pendidikan Rendah & 193 & \\
\hline Pendidikan Tinggi & 26 & 7,3 \\
\hline$\quad>$ Rp 2.700.000 & 16 & 92,7 \\
\hline
\end{tabular}

Tabel 2

Hubungan Interaksi Sosial dan Kualitas Hidup pada lansia di wilayah kerja Puskesmas Bangkala, Kec.Manggala, Kota Makassar Tahun 2019

\begin{tabular}{|c|c|c|c|c|c|c|c|c|c|}
\hline \multirow{3}{*}{$\begin{array}{l}\text { Variabel } \\
\text { Interaksi sosial }\end{array}$} & \multicolumn{4}{|c|}{ Kualitas Hidup } & \multirow{2}{*}{\multicolumn{2}{|c|}{ Total }} & \multirow[t]{2}{*}{ OR } & \multirow{2}{*}{$\begin{array}{c}\mathbf{P} \\
\text { Value }\end{array}$} & \multirow{2}{*}{$\begin{array}{r}95 \% \\
\text { CI }\end{array}$} \\
\hline & & ang & Baik & & & & & & \\
\hline & $\mathbf{N}$ & $\%$ & $\mathbf{N}$ & $\%$ & $\mathbf{N}$ & $\%$ & & & \\
\hline Kurang & 51 & 23,3 & 26 & 11,9 & 77 & 35,2 & & & \\
\hline Baik & 31 & 14,2 & 111 & 50,7 & 142 & 64,8 & 7,024 & 0,003 & $3,787-$ \\
\hline Jumlah & 82 & 37,4 & 137 & 62,6 & 219 & 100 & & & 13,027 \\
\hline
\end{tabular}

